\title{
WUJUD REVITALISASI WISATA SPIRITUAL SEBAGAI EKSPANSI KAPITALISME PARIWISATA
}

\author{
Nyoman Sri Subawa ${ }^{1)}$ dan Ni Wayan Widhiasthini ${ }^{2)}$ \\ 1) Universitas Pendidikan Nasional Alamat Rumah: Jl. Tukad Pakerisan No. 74 Denpasar \\ 2) STISPOL Wira Bhakti Denpasar
}

\section{Email: shribawa@gmail.com dan widhiasthini74@yahoo.co.id}

\begin{abstract}
ABSTRAK. Era postmodern yang sangat terkait dengan globalisasi telah membawa dampak terhadap pergeseran kehidupan masyarakat. Terutama sangat tampak pada perubahan pola tindakan, dan gaya hidup yang cenderung praktis, dan serba "instant". Hal ini tidak terlepas dari semakin ketatnya persaingan yang terjadi pada berbagai bidang, sehingga diperlukan kecerdasan tersendiri dalam pemanfaatan ruang dan waktu. Termasuk dalam melakukan aktivitas berwisata sebagai bentuk tindakan untuk melepaskan diri dari berbagai kesibukan dan rutinitas, serta kegiatan yang berhubungan dengan pemenuhan kebutuhan kerohanian yang lebih dikenal dengan spiritualitas. Dengan demikian keseimbangan hidup dapat dicapai, sehingga produktivitas dan profesionalisme pada bidang masing-masing dapat semakin meningkat. Kebutuhan masyarakat untuk memenuhi kedua hal tersebut mendapat perhatian dari pihak pengusaha yang bergerak di bidang kepariwisataan, khususnya biro perjalanan wisata dengan menawarkan paket wisata spiritual. Merupakan terobosan baru dengan menggabungkan konsep berwisata, dan kegiatan spiritual yang sebelumnya dilakukan secara terpisah. Penawaran ini mendapat sambutan dari masyarakat, terbukti dengan banyaknya masyarakat yang mengikuti program tersebut, baik yang tergabung dalam organisasi maupun pribadi. Hal ini sangat menarik untuk dicermati dari aspek sosial ekonomi, mengingat keterlibatan dari pengusaha pada bidang ini sesungguhnya tidak terpisah dari ekspansi kapitalisme, yang telah merambah bidang pariwisata.

Kata Kunci: wisatawan, perjalanan spiritual, kapitalisme, revitalisasi
\end{abstract}

JUDUL BAHASA INGGRIS?

ABSTRACT. The postmodern era related to globalism, it brought impacts to our live in society (as the result, this process globalism) has brought impacts on the various of human live such as action (culture pattern) and lifestyles (social relation). This happen as the result of the competition in various fields that need intelligent to exploiting space and time. One of the impacts of globalism is the activities of tourism as a form of bustle in daily routine. Tourism also related to spiritual needs that we known as spirituality. Thus, work-life balance can be achieved. Those of needs (work-life balance) got many attentions from the tourism business, such as travel agent that offering spiritual packages. This kind of packages/breakthrough was welcomed by the community, many people (individuals or groups) are joined in this activities. It ought to be observed from the social-economic aspects. As we known the involvement of tourism business can not be separated from the expansion of capitalism that has penetrated into the word of tourism.

Keyword: tourist, journey of spiritual, capitalism, revitalization.

\section{PENDAHULUAN}

Pengusaha yang bergerak di bidang kepariwisataan seperti biro perjalanan wisata menangkap peluang bisnis dengan menawarkan berbagai produk jasa seperti paket tour mengunjungi pura-pura dan situs bersejarah umat Hindu, yang dilengkapi dengan kegiatan wisata mengunjungi daerah tujuan wisata yang ada di daerah tersebut. Untuk kemudian produk jasa tersebut diperkenalkan kepada masyarakat sebagai wisata spiritual, yang akhirnya menjadi pilihan masyarakat dan sangat digemari masyarakat. Masyarakat mendapat dua keuntungan sekaligus, yaitu tetap dapat memenuhi tujuan utama melakukan persembahyangan di pura-pura, dan pada sisi yang lain juga mendapat kesempatan mengunjungi objek-objek pariwisata. Paket wisata yang ditawarkan tersebut sesuai dengan konsep pariwisata itu sendiri, seperti pernyataan Muljadi (2009:7) bahwa "pariwisata merupakan aktivitas, pelayanan dan produk hasil industri pariwisata 
yang mampu menciptakan pengalaman perjalanan bagi wisatawan".

Berdasarkan fenomena tersebut dapat dinyatakan bahwa telah terjadi perubahan pandangan dan perilaku di kalangan masyarakat dalam melakukan perjalanan wisata. Paket tersebut sarat akan kepentingan ekonomi bisnis, sebagai bagian dari kegiatan kapitalis yaitu dengan memadukan konsep wisata dan perjalanan spiritual di satu sisi, namun tetap memberikan kontribusi bagi pengusaha. Kreativitas para pengusaha sesungguhnya tidak terlepas dari pola dan gaya hidup masyarakat di era postmodern. Perubahan sosial yang meliputi pola perilaku, hubungan sosial, lembaga dan struktur sosial pada waktu tertentu dalam hal melakukan tindakan spiritual maupun berwisata akan menjadi pokok bahasan dalam penelitian ini. Perubahan tersebut dikategorikan sebagai revitalisasi dari wisata spiritual, mengingat kegiatan tersebut sesungguhnya telah berlangsung lama, tetapi saat ini dilakukan dengan konsep tindakan yang berbeda, sebagai akibat dari ekpansi kapitalisme pariwisata. Mengacu dari fenomena tersebut maka masalah dalam penelitian ini adalaha "bagaimanakah wujud revitalisasi wisata spiritual sebagai ekspansi kapitalisme pariwisata bagi masyarakat penekun wisata spiritual dan pengusaha yang bergerak di bidang kepariwisataan?". Hasil dari penelitian ini merupakan pilahan dari hasil penelitian Hibah Fundamental dengan topik "Revitalisasi Wisata Spiritual Sebagai Ekspansi Kapitalisme Pariwisata".

Penelitian kepariwisataan sesungguhnya telah banyak dilakukan, beberapa penelitian yang dipandang terkait serta memberikan inspirasi bagi peneliti adalah penelitian oleh Rizkia (2009) yang berjudul "Potensi Obyek Wisata Budaya dan Spiritual di Kabupaten Wonogiri". Hasil penelitian menunjukkan bahwa obyek wisata di Kabupaten Wonogiri cenderung memiliki nilai budaya dan spiritual yang bisa dikemas dalam bentuk paket wisata 'one day'dengan nama Paket Wana Wisata Setren Girimanik Tour, Paket Wisata Sumbernyowo Tour, Paket Wisata Kahyangan Tour dan Paket Wisata Sembukan Tour. Hal tersebut dapat dijadikan alternatif wisata yang didalamnya terdapat obyek-obyek spiritual. Penelitian lainnya dilakukan oleh Sunary dengan judul "Budaya Spiritual Petilasan-Petilasan di Gunung Selok dalam Konteks Pemahaman oleh Masyarakatnya". Hasil penelitian menunjukkan bahwa Gunung Selok mempunyai nilai budaya dan spiritual sebagai pendapatan daerah dan bekerja sama dengan masyarakat untuk membuat paket wisata kebudayaan atau spiritual ( http://garuda.kemdiknas.go.id ). Kedua hasil penelitian tersebut hanya menunjukkan potensi objek wisata spiritual yang dimiliki oleh lokasi penelitian namun belum menunjukkan keterlibatan pengusaha kepariwisataan yang merupakan representasi dari kapitalisme pariwisata. Penelitian tersebut memberikan inspirasi bagi peneliti untuk mengupas keterlibatan pengusaha kepariwisataan yang mengaktifkan modalnya dengan menjual paketpaket wisata spiritual. Pada sisi yang lain respon dari masyarakat juga dicermati lebih jauh dimana hal tersebut diabaikan oleh kedua penelitian diatas.

Konsep yang menjadi acuan dalam pembahasan meliputi, revitalisasi wisata spiritual, yaitu berbagai macam kegiatan wisata dengan didukung berbagai fasilitas serta layanan yang diberikan oleh masyarakat, pengusaha, pemerintah yang dilakukan oleh seseorang atau sekelompok orang dengan tujuan untuk memenuhi hasrat kehidupan rohani. Kedua, kapitalisme pariwisata adalah kegiatan menanamkan modal, serta mengembangkan usaha yang dilakukan oleh seseorang atau sekelompok orang pada bidang usaha penunjang kepariwisataan. Sedangkan teori yang dijadikan landasan dalam pembahasan meliputi teori Perubahan Sosial, menurut Sztompka (2004:3) adalah perubahan yang terjadi di dalam atau mencakup sistem sosial, lebih tepatnya terdapat perbedaan antara sistem tertentu dalam jangka waktu berlainan. Teori Tindakan Komunikatif yang dikemukakan oleh Habermas (2006:231), dibedakan atas dua hal, yaitu tindakan komunikatif dan tindakan rasional bertujuan. Teori selanjutnya adalah Wacana Pengetahuan/Kekuasaan yang dicetuskan oleh Foucault (Haryatmoko, 2002:9-13). Secara esensial dapat dinyatakan bahwa, dimana terdapat pengetahuan maka saat itu kekuasaan terbentuk, demikian pula kekuasaan akan melahirkan pengetahuan. Selain itu dipergunakan pula Teori Praktik Sosial yang dicetuskan oleh Pierre Felix Bourdieu (Harker,dkk.,1990:13), yaitu (habitus $\mathrm{x}$ modal $)+$ ranah $=$ praktik, bahwa relasi antara individu dan struktur dengan relasi antara habitus dan ranah yang melibatkan modal.

Kerangka pemikiran dalam penelitian dapat digambarkan sebagai berikut.: 


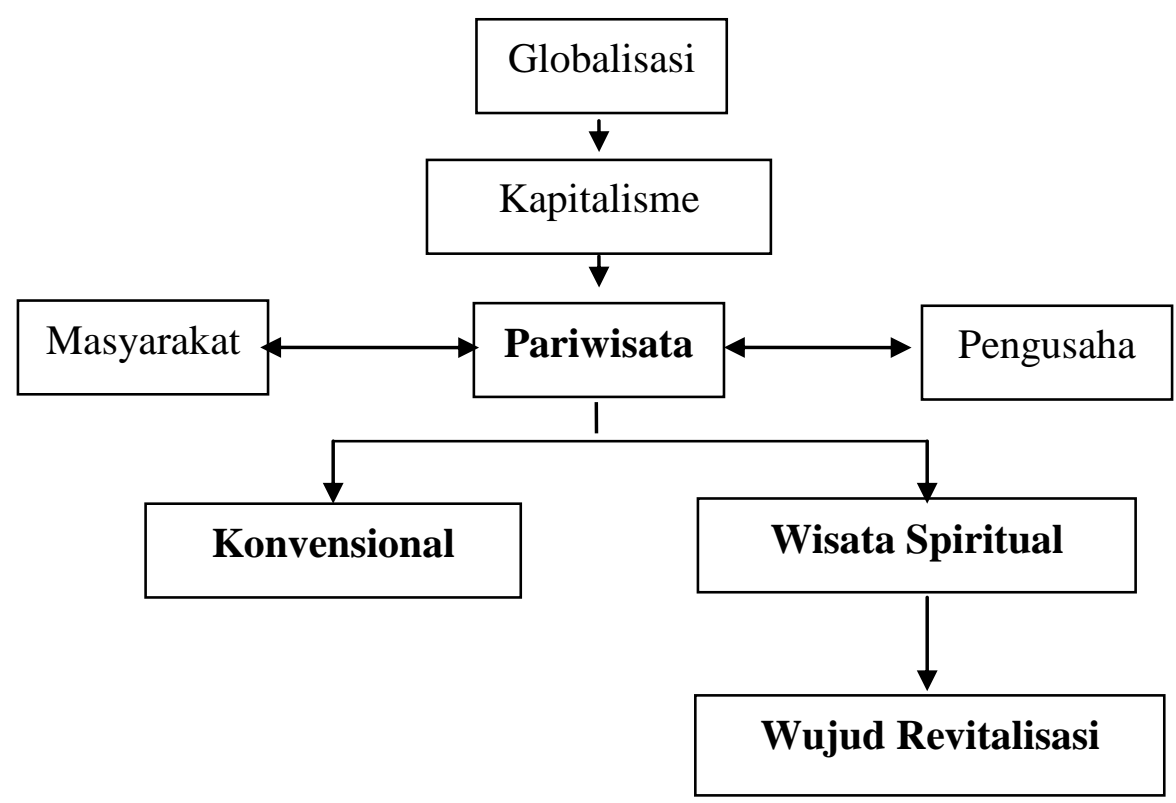

Gambar 1. Kerangka Pemikiran Penelitian.

\section{METODE}

Terdapat beberapa hal penting dimuat dalam metode, meliputi: desain dan rancangan penelitian, bahwa penelitian ini bertujuan untuk mengungkap dan menjawab permasalahan mengenai wisata spiritual sebagai wujud ekspansi kapitalisme pariwisata dengan metode kualitatif. Data yang berhasil dikumpulkan dianalisis secara deskriptif kualitatif dan interpretatif. Objek material dalam penelitian ini adalah wisata spiritual, sedangkan subjek formalnya adalah bidang sosial ekonomi, dan budaya. Penelitian ini menyelaraskan beberapa disiplin ilmu, khususnya bidang sosial ekonomi, lebih mengutamakan penggunaan teori-teori kritis, sebagai bagian dari teori-teori postmodern sebagai alat analisis utama. Penelitian ini menggunakan paradigma sosial kritis, serta dipergunakan secara ekletik, berupaya membongkar, dan memahami struktur dominasi dalam masyarakat kapitalis industri yang terjadi dalam bidang kepariwisataan. Hal ini terkait dengan wisata spiritual yang digunakan para kapitalis sebagai wujud lain pengembangan pariwisata. Penelitian juga mencermati perubahan pola tindakan sosial masyarakat yang menggabungkan kegiatan wisata dan kegiatan spiritual, yang lebih menekankan aspek kepraktisan, dan nilai ekonomi.

Penelitian ini dilakukan di Kota Denpasar khususnya bagi pihak-pihak yang terlibat dalam wisata spiritual. Kota Denpasar ditetapkan sebagai lokasi penelitian didasari beberapa pertimbangan, salah satunya adalah banyak terdapat perusahaan Biro Perjalanan Wisata yang menawarkan paketpaket perjalanan wisata spiritual ke berbagai daerah di Indonesia, dan luar negeri. Jumlah biro perjalanan wisata di kota Denpasar sesungguhnya cukup banyak, salah satu biro perjalanan wisata yang akan dirujuk sebagai lokasi penelitian adalah Bali Daksina Wisata Tour and Travel, dikarenakan memiliki beberapa keunggulan dibandingkan dengan biro perjalanan wisata (BPW) lainnya. Hal ini dapat dijelaskan sebagai berikut: (1) lebih memfokuskan pada bidang pelayanan paket wisata spiritual kepada masyarakat (2) berada pada lokasi strategis (3) menetapkan biaya yang cukup murah dalam menawarkan paket wisata spiritual kepada masyarakat, (4) dipercaya oleh berbagai instansi pemerintah dan swasta, organisasi sosial kemasyarakatan, lembagalembaga pendidikan, perkumpulan keluarga, dan berbagai lapisan masyarakat untuk mengkoordinasikan kegiatan wisata spiritual, serta (5) memiliki jaringan usaha wisata yang luas diberbagai daerah tujuan wisata spiritual.

Jenis data dalam penelitian ini adalah data kualitatif yang berhasil dikumpulkan yang tidak berbentuk angka, yaitu berupa kata-kata, kalimat, dan ungkapan yang diperoleh dari informan sebagai sumber dari data primer. Informan terdiri dari pihak pengelola tour/wisata spiritual 
(manajemen), pemandu wisata, pengguna jasa wisata spiritual (masyarakat). Penelitian ini menggunakan teknik pengumpulan data yang meliputi pengamatan, wawancara mendalam, dan studi dokumen. Peneliti merupakan instrument utama dalam penelitian ini, dengan menggunakan pedoman wawancara, alat perekam, dan kamera sebagai alat bantunya. Penentuan informan dalam penelitian ini dilakukan secara purposive. Sehingga dipandang perlu dipilih informan yang mempunyai pengetahuan dan pengalaman serta kompetensi pada bidang pengelolaan wisata spiritual, serta masyarakat yang sering menjalani kegiatan tersebut. Dalam hal ini peneliti sendirilah yang menentukan dan menetapkan informan yang akan dipilih. Selain itu penentuan informan juga dilakukan secara judgment dan convenience. Adapun jumlah informan dalam penelitia ini adalah 9 (sembilan) orang yang merupakan representasi dari unsur masyarakat penekun wisata spiritual, serta pengelola jasa kepariwisataan. Hasil pengolahan data disajikan tidak dalam bentuk angka.

\section{HASIL DAN PEMBAHASAN Wujud Revitalisasi Wisata Spiritual}

Globalisasi yang ditandai oleh perbedaanperbedaan dalam kehidupan telah mendorong pembentukan definisi baru tentang berbagai hal dan memunculkan praktik kehidupan yang beragam. Berbagai dimensi kehidupan mengalami redefinisi dan diferensiasi terjadi secara meluas yang menunjukkan sifat relatif suatu praktik sosial (Abdullah, 2006:107). Praktik sosial sebagaimana yang dimaksud di atas tentulah mencakup praktik keagamaan, yang dilakukan oleh masyarakat, dan disinyalir telah mengalami perubahan dengan faktor penyebabnya adalah globalisasi yang membawa serta budaya global. Lebih lanjut juga dinyatakan bahwa cara-cara orang mempraktekkan agama juga mengalami perubahan, bukan karena agama mengalami proses kontekstualisasi sehingga agama embedded di dalam masyarakat, tetapi juga karena budaya yang mengkontekstualisasi agama itu merupakan budaya global, dengan tata nilai yang berbeda.

Tidak bisa dipungkiri bahwa arus besar globalisasi telah melahirkan masyarakat global yang hidup pada jaman postmodern dan akrab dengan budaya kontemporer. Perkembangan masyarakat kontemporer yang dicirikan oleh kegandrungan pada budaya popular, budaya komoditas, gaya hidup konsumerisme, dan permainan citra (image) pada tingkat kedalaman tertentu telah menyeret berbagai realitas ritual keagamaan ke dalam ruang-ruang pengaruhnya (Piliang, 2004:336). Fenomena sebagaimana diungkapkan Piliang juga terjadi pada perubahan sikap, pola dan cara masyarakat dalam melakukan perjalanan spiritual, dari bentuk perjalanan yang konvensional mengarah pada bentuk perjalanan berbeda yang dilakukan pada era postmodern. Perjalanan tersebut tidak lagi mengacu pada satu tujuan spiritualisasi semata, tetapi bersifat multikompleks seperti yang diungkapkan Piliang (2004:336) bahwa "ketika ritual keagamaan terseret ke dalam ruang-ruang pengaruh tersebut (komoditi, konsumerisme, citra), maka ia akan terperangkap di dalam sifat-sifat kedangkalan dan artifisialnya, sebaliknya akan semakin menjauhkannya dari makna-makna dan nilai-nilai hakikinya." Terkait dengan hal tersebut, dipandang perlu untuk membahas wisata spiritual dalam bentuknya yang konvensional, dan wisata spiritual yang sudah dan sangat terkait dengan globalisasi yaitu wisata spiritual pada era postmodern khususnya yang dilakukan oleh umat Hindu di Bali. Mengingat pemeluk agama Hindu di Bali jumlahnya melebihi pemeluk agama lainnya, sehingga praktek-praktek keagamaan yang dilakukan dapat diamati dan ditelusuri secara mendalam, sebagai berikut.

\section{Perjalanan Spiritual Konvensional}

Fenomena wisata spiritual juga tidak luput dari gerak perubahan yang merupakan dinamika dalam masyarakat itu sendiri. Sesungguhnya perjalanan spiritual telah dilakukan sejak dahulu oleh para penekunnya, namun tanpa menggabungkannya dengan kegiatan wisata. Seperti yang dilakukan oleh Mikarningsih, seorang informan berusia 52 tahun yang berprofesi sebagai Pegawai Negeri Sipil. Ia menyatakan sangat sering melakukan perjalanan spiritual (persembahyangan) ke beberapa Pura yang tersebar di daerah Bali, khususnya ke Pura Besakih, berikut adalah pernyataannya.

"Dulu ketika masih kecil untuk tangkil ke Pura Besakih biasanya hanya saat Piodalan Ida Betara Turun Kabeh Purnama Kedasa, dari Jembrana tempat saya tinggal itu bukan main susahnya, harus disiapkan jauh-jauh hari dan bisa makan waktu lebih dari satu hari hanya untuk satu tujuan saja meskipun sudah naik kendaraan bus yang seperti jaman dulu. Harus bawa perbekalan 
makanan yang banyak karena tidak banyak penjual seperti sekarang, harus siapkan baju ganti juga karena lamanya perjalanan. Bahkan ngak boleh dibilang-bilang kalau mau kesana takut ngak berhasil saking jauhnya, orang tua saya mengatakan kalau kita bilang mau tangkil ya harus tangkir'. (wawancara dilakukan Juli 2011)

Hal yang sama juga dinyatakan oleh informan Parwati, Budiana, dan Yasa ketika peneliti menanyakan bagaimana perjalanan spiritual yang dilakukan secara konvensional terutama pada saat moda transportasi, dan akomodasi, belum berkembang pesat seperti saat ini. Ketiganya menyatakan jika perjalanan spiritual yang dilakukan dahulu terbatas hanya mengunjungi situs-situs keagamaan di sekitar wilayah Bali saja, belum merambah daerahdaerah di luar Bali apalagi sampai keluar negeri seperti yang terjadi saat ini. Secara khusus informan Yasa menyatakan jika perjalanan spiritual pada masa kecilnya juga sering dilakukan secara komunal, dengan keluarga besarnya ataupun sering melibatkan semeton dadia paibon (ikatan kekerabatan dalam satu pura). Terkait kegiatan tersebut, para peserta membagi diri sesuai dengan kemampuannya masing-masing untuk mensukseskan perjalanan spiritual. Seperti ada yang menangani transportasi, menyediakan alas tidur, perbekalan makanan dan minuman hingga obat-obatan, namun untuk sarana upakara ataupun banten persembahan dipersiapkan secara mandiri oleh para peserta. Meskipun perjalanan spiritual yang diuraikan di atas berbentuk konvensional, dilakukan secara tradisional tetapi para pesertanya tetap mengorganisir diri, melakukan perencanaan, menyiapkan pendanaan yang dikelola dan dipersiapkan dengan prinsip "dari, oleh, dan untuk mereka sendiri".

Secara konseptual hal tersebut memiliki kesesuaian dengan konsep kegiatan spiritual, sebagaimana tercantum pada kajian pustaka, yang salah satunya adalah mengunjungi situssitus keagamaan seperti candi, dan pura. Sedangkan secara teoritik, data-data yang diungkapkan informan tersebut di atas merupakan realisasi dari teori Tindakan Komunikatif bahwa apa yang dilakukan oleh para informan dalam kegiatan perjalanan spiritual berorientasi pada saling pemahaman di antara subjek-subjek yang berinteraksi dan diatur dalam norma-norma yang disepakati bersama. Tentunya norma yang dimaksud adalah norma, dan keyakinan terhadap agama tertentu, yaitu agama Hindu.

Berdasarkan amatan peneliti terhadap kondisi perjalanan spiritual yang dilakukan oleh masyarakat, mereka banyak melakukannya terutama ketika ada momentum upacara. Sampai saat inipun perjalanan wisata spiritual yang hanya memiliki satu tujuan, yaitu hanya untuk melakukan persembahyangan masih dilakukan berbagai lapisan masyarakat. Fenomena tersebut peneliti istilahkan dengan perjalanan spiritual konvensional, karena bentuk perjalanannya sangat berbeda dengan perjalanan spiritual yang berkembang seperti saat ini, bahkan telah berbaur dengan kegiatan wisata. Adapun perjalanan spiritual konvensional seperti yang banyak terjadi, pada umumnya dilakukan hanya dalam lingkup wilayah Propinsi Bali, tidak ataupun belum merambah daerah-daerah di luar Bali apalagi luar negeri.

Terkait perjalanan spiritual konvensional, masyarakat dapat melakukannya secara mandiri hanya terbatas pada keluarga kecilnya saja, secara bersama-sama dengan keluarga besarnya, ataupun mengikuti kegiatan sejenis yang juga dilakukan oleh organisasi, instansi, sekolahsekolah tempat mereka menuntut ilmu. Mereka datang secara bersama-sama dengan menggunakan kendaraan-kendaraan yang bisa menampung penumpang dalam jumlah cukup banyak. Biasanya saat-saat seperti itu pengusaha tansportasi sangat diuntungkan, karena banyaknya permintaan terhadap jasa pengangkutan penumpang. Jenis kendaraan seperti bus-bus pariwisata, datang silih berganti mengangkut rombongan siswa, mahasiswa, pegawai, seka banjar, anggota seka karang taruna (muda mudi), anggota subak, dan perkumpulan lainnya. Meskipun perjalanan yang mereka lakukan terorganisir, jika ditelisik dari tujuannya maka perjalanan spiritual tersebut tetap digolongkan bersifat konvensional. Terkait dengan unsur teoritik, hal tersebut digolongkan sebagai habitus yaitu hasil ketrampilan dan tindakan praktis yang sering tidak disadari dan kemudian berkembang dalam lingkungan sosial tertentu.

Selain mengungkapkan data yang diperoleh dari informan masyarakat penekun perjalanan spiritual konvesional di atas, tentunya dipandang perlu untuk mengetahui lebih jauh dari sisi pengusaha jasa transportasi seperti para pemilik kendaraan yang melayani kebutuhan masyarakat. 
PT. Bali Daksina Wisata sebagai perusahaan yang bergerak di bidang kepariwisataan juga menyediakan beberapa unit kendaraan, dari jenis mini bus hingga bus untuk disewakan kepada masyarakat. Seperti diungkapkan oleh Kusnadi, staf yang bertugas menangani divisi jasa pengangkutan bahwa mereka juga menyediakan beberapa jenis kendaraan untuk disewakan kepada masyarakat. Kusnadi menyatakan bahwa dalam waktu-waktu tertentu, seperti selama piodalan di Pura Besakih kendaraan yang dimiliki PT. Bali Daksina Wisata terus beroperasi disewa oleh masyarakat hanya untuk perjalanan spiritual semata. Masyarakat hanya menyewa kendaraan dalam waktu tertentu, sedangkan keperluan lainnya mereka urus sendiri mengingat mereka hanya fokus pada satu tujuan, dan perjalanan yang dilakukan masih terbatas dalam lingkup propinsi Bali. Pelaku perjalanan spiritual juga tidak memerlukan sarana akomodasi, karena biasanya perjalanan tersebut dapat mereka selesaikan dalam satu hari saja. Sedangkan terkait keperluan logistik, seiring perkembangan waktu maka segala keperluan tersebut dengan mudah dapat dipenuhi baik di lokasi yang dituju maupun pada sepanjang rute yang di lalui.

Perlu diketahui bahwa sebenarnya perusahaan biro perjalanan seperti PT. Bali Daksina Wisata juga melayani kebutuhan masyarakat secara menyeluruh untuk kepentingan melakukan perjalanan spiritual seperti tirta yatra meskipun hanya disekitar wilayah Propinsi Bali. Baik penyediaan logistik, sarana upakara (banten) di samping transportasi, namun masyarakat yang melakukan perjalanan spiritual biasanya lebih memilih untuk mempersiapkan segala keperluan lain di luar transportasi secara mandiri. Seperti yang diungkapkan oleh Maharani, seorang informan yang berusia 14 (empat belas) tahun, tercatat sebagai siswa SMP (Sekolah Menengah Pertama) pada sebuah sekolah yang berstatus negeri di Kota Denpasar. Meskipun masih duduk di bangku SMP, siswa-siswa di sekolah tersebut diarahkan untuk mengorganisir diri secara mandiri untuk kelancaran kegiatan Tirta Yatra yang secara rutin dilaksanakan sekolahnya.

Secara teoritis penyelenggaraan perjalanan spiritual Tirta Yatra sebagaimana tersebut di atas, merupakan realisasi atas Teori Tindakan Komunikatif, baik Tindakan Rasio Bertujuan yang berorientasi pada kesuksesan dan dimensi kerja, serta bersifat instrumental dalam arti mematuhi aturan-aturan teknis dengan memilih sarana yang tepat untuk mewujudkan tujuan. Terkait dengan teori yang dipergunakan sebagai acuan dalam penelitian ini, perjalanan spiritual yang bersifat konvensional tersebut merupakan realisasi atas Teori Perubahan Sosial. Jika diamati dari masa ke masa, meskipun bersifat konvensional tetapi perubahan sosial tetap saja telah terjadi, sebagaimana pendapat Starsser dan Randall (dalam Sztompka, 2004:3) bahwa ketika berbicara perubahan sosial, haruslah dibayangkan sesuatu yang terjadi setelah jangka waktu tertentu; berhubungan dengan perbedaan keadaan yang diamati antara sebelum dan sesudah jangka waktu tertentu. Dalam penelitian ini, yang sangat tampak terjadi adalah perubahan pada pola, cara kerja, pembagian tugas yang dilakukan oleh para pelaksana perjalanan spiritual. Sedangkan tujuan dan hakekat yang akan dituju tetapkah sama, yaitu sebagai perwujudan rasa bhakti terhadap Tuhan.

\section{Perjalanan Spiritual bagian dari Kegiatan Wisata}

Pembahasan tentang wisata spiritual yang terjadi pada era postmodern tentulah sangat kompleks, membahas segala sesuatu yang terkait dengan kegiatan spiritual yang pelaksanaannya sangat berbeda dengan perjalanan spiritual konvensional. Dalam hal ini menelusuri perbedaan praktek perjalanan itu sendiri, baik terkait dengan pihak-pihak yang dilibatkan, maupun hakekat dan tujuan yang ingin dicapai. Perubahan dalam praktek perjalanan spiritual tentu saja sangat dipengaruhi oleh waktu, zaman, dan yang tak kalah pentingnya, serta selalu menjadi "kambing hitam" atas segala hal yang terjadi adalah "globalisasi" yang kehadirannya membawa serta "budaya global".

Kekuasaan globalisasi sangatlah kuat, ia merambah segala bidang kehidupan. Tidak saja saja terbatas pada bidang ekonomi, ideologi, teknologi, media massa, kebudayaan, tetapi juga perubahan pada praktek-praktek keagamaan itu sendiri. Budaya global sendiri adalah sebuah arus yang dibawa oleh gelombang globalisasi, pada titik inilah terjadi tarik menarik yang sangat kuat dengan budaya lokal (local genius) yang memang telah mengakar dan menjadi praktek kehidupan masyarakat. Piliang (2004:285) memberikan pernyataan bahwa budaya global ( $g$ lobal culture) adalah konsep yang menjelaskan tentang mendunianya berbagai aspek kebudayaan, yang di dalam ruang global tersebut terjadi proses 
penyatuan, kesalingberkaitan, dan kesalingterhubungkan. Kehadiran budaya global semakin kuat ketika masa postmodern tiba, yang ditandai oleh aktivitas, budaya, dan ruang gerak masyarakat yang berbeda dari era modern. Sebagaimana dinyatakan Featherstone (2001:5) bahwa istilah "postmodern" lebih kuat didasarkan pada suatu negasi dengan modern, suatu pembebasan, perpecahan dengan atau pergeseran dari gambaran definitif modern, dengan penekanan pada pengertian perpindahan rasional. Artinya bahwa segala sesuatu yang berada dalam lingkup postmodern berbeda dengan yang terjadi pada era modern. Demikian pula yang terjadi pada praktek perjalanan spiritual yang dilakukan oleh masyarakat Hindu di Bali, seperti uraian di bawah ini.

Seperti yang dilakukan oleh Parwati (53 tahun) seorang karyawati instansi swasta di Denpasar. Informan ini sudah mengikuti beberapa kali perjalanan Tirta Yatra ke Gunung Salak, Lumajang, dan Semeru. Berikut adalah kutipan wawancara dengan Parwati.

"Saya senang ikut Tirta Yatra ke luar Bali, seperti ke Gunung Salak, Lumajang, Semeru sekalian tour, berwisata. Kalau pergi Tirta Yatra saya pasti menggunakan jasa travel, sampai saya tidak tahu, tidak pernah hitung apakah kalau pergi dengan travel bisa lebih murah atau lebih mahal dari pada urus sendiri. Selain itu juga kalau pergi sendiri, tanpa travel bisa jadi susah, harus cari makan sendiri, hotel sendiri, cara memuja di masing-masing pura juga saya tidak tahu. Harus menghadap ke mana, bagaimana urutan sembahyangnya tidak tahu, sebab cara memuja di masingmasing pura bisa berbeda. Tapi kalau sudah pakai travel rasanya tenang, aman karena mereka sudah kasih tahu semuanya malahan sampai banten dan peralatan sembahyangnya sudah disiapkan." (wawancara dilakukan Juli 2011)

Hal yang sama juga diterjadi pada Budiana, seorang informan yang berusia 55 tahun, yang menekuni profesi sebagai dosen pada perguruan tinggi swasta di Denpasar. Ketika peneliti memintanya untuk berbagi pengalaman tentang perjalanan spiritual yang sangat sering ia lakukan, Budiana yang juga seorang Bendesa Adat (tokoh masyarakat), pemerhati agama dan budaya menuturkan sebagai berikut.
"Intensitas perjalanan saya untuk melakukan Tirta Yatra sangat sering, baik dilakukan dengan krama (warga) desa adat, keluarga, maupun terlibat dalam kelompokkelompok lain. Sudah berulang-ulang saya melakukan perjalanan ke Lombok melalui Pelabuhan Penyeberangan Padangbai, ataupun melalui transportasi udara. Mengunjungi Pura Suranadi, Pura Lingsar, Pura Batu Bolong, Candi Narmada, dan Mayura, sebelum atau sesudah persembahyangan biasanya disisipi dengan kunjungan ke objek wisata atau pusat oleholeh. Demikian juga dengan Tirta Yatra Gunung Salak. Saking seringnya ikut, saya jadi hafal rute-rute yang dituju. Saya juga sudah pernah ikut Tirta Yatra ke India. Dalam melakukan perjalanan, saya pasti meminta bantuan biro perjalanan untuk mengurus segala keperluannya. Meskipun bisa jadi lebih mahal dari pada diurus sendiri, tapi saya merasa tenang karena semua sudah diurus travel. Bahkan sampai banten juga sudah dipersiapkan oleh travel. Menggunakan travel juga sangat membantu saya untuk mengetahui tempat-tempat yang menarik untuk dikunjungi, terutama tempat wisata baru. Mereka juga bisa memberikan informasi yang up to date terkait tujuan wisata, informasi itu didapat dari pemandu yang biasanya selalu menyertai perjalanan. Jadi biro perjalanan sangat membantu masyarakat untuk mengetahui tempat-tempat suci untuk dikunjungi, membantu menambah pengalaman baru, melihat lingkungan di luar dengan lebih luas." (wawancara dilakukan Juli 2011)

Selain dilakukan secara individual dalam artian lingkup keluarga, kegiatan wisata spiritual juga dilakukan oleh instansi-instansi pemerintah dengan cara menyisihkan atau mengalokasikan dana tertentu agar semua karyawan pada instansi tersebut dapat ikut serta. Dalam artian mereka tidak perlu mengeluarkan dana dari kantongnya sendiri untuk keperluan perjalanan tersebut. Hal tersebut memang banyak dilakukan oleh instansiinstansi pemerintah, bahkan menurut amatan peneliti jika terjadi perjalanan seperti itu hampir semua pegawai yang bekerja pada instansi tersebut ikut serta sehingga aktivitas pelayanan tidak dapat berjalan optimal. Salah seorang pejabat di lingkungan Pemerintah Daerah Tingkat II yang tergolong memiliki PAD (Pendapatan Asli 
Daerah) tertinggi di Bali yaitu Agung (45) tahun, menyatakan bahwa hampir setiap enam bulan instansi yang dipimpinnya rutin melakukan Tirta Yatra. Adapun tujuan favorit mereka adalah Gunung Salak. Karena paket Tirta Yatra Gunung Salak yang ditawarkan oleh travel meliputi tujuantujuan wisata favorit di Ibu Kota Jakarta, mereka merasa senang sekali karena setelah melakukan persembahyangan langsung diajak mengunjungi TMII (Taman Mini Indonesia Indah), See Word, Ancol, Dufan, Monas, lalu wisata belanja murah di pusat kerajinan kulit Tajur Bogor, ITC Mangga Dua, dan Cempaka Mas. Paket ini sangat membantu, sebab sampai pegawai yang eselonnya kecil juga jadi tahu kondisi kota Jakarta, tahu rasanya naik pesawat, tidur di hotel, dan makan enak di restoran. Karena mereka yakin jika berangkat dengan biaya sendiri cita-cita untuk mengunjungi ibu kota sulit tercapai.

Dari pendapat informan tersebut di atas, dikaitkan dengan konsep dan teori yang dipergunakan dalam penelitian ini maka perjalanan spiritual yang mereka lakukan dapat digolongkan sebagai wujud revitalisasi wisata spiritual. Sesungguhnya perjalanan mengunjungi tempat-tempat suci telah ada dan berlangsung sejak dahulu, namun saat ini perjalanan tersebut telah mengalami proses revitalisasi melalui penggabungan dengan kegiatan wisata. Karena selain tujuan utama untuk melakukan persembahyangan, mereka juga melakukan perjalanan wisata mengunjungi objek-objek wisata, dan pusat perbelanjaan, bermalam di hotel, makan di restoran yang kesemua pelaksanaannya ditangani oleh travel. Kesemua sarana dan prasarana yang mereka nikmati tersebut adalah merupakan produk wisata, seperti dikemukakan dalam Pasal 14 Undang-undang No.10 Tahun 2009 tentang Kepariwisataan.

Selain mengacu pada undang-undang, fenomena perjalanan yang dilakukan kedua informan tersebut juga memiliki kesesuaian dengan konsep revitalisasi wisata spiritual yaitu berbagai macam kegiatan wisata dengan didukung berbagai fasilitas serta layanan yang disediakan oleh masyarakat, pengusaha, pemerintah yang dilakukan oleh seseorang atau sekelompok orang dengan tujuan memenuhi hasrat kehidupan rohani. Dalam kaitannya dengan ranah teoritis, tampak betapa kondisi tersebut sangat erat terkait dengan Teori Perubahan Sosial sebagaimana dikemukakan Farley (Sztompka, 2004:5) bahwa "perubahan sosial adalah perubahan pola perilaku, hubungan sosial, lembaga dan struktur sosial pada waktu tertentu. Demikian juga halnya pola pikir, dan tindakan masyarakat sudah berubah seiring dengan perkembangan waktu, ketersediaan sarana dan prasarana yang disediakan dan dijual oleh travel dalam rangka perjalanan wisata dan kegiatan spiritual. Dari yang semula bersifat konvensional, hanya untuk kepentingan perjalanan spiritual semata, kini telah mengalami perubahan, dimana selain untuk melakukan persembahyangan juga sekaligus untuk kegiatan wisata.

Perjalanan spiritual sebagai bagian dari kegiatan perjalanan wisata yang dilakukan oleh informan di atas merupakan praktik sosial sebagaimana Teori Praktik Sosial yang dikemukan oleh Bourdieu, yaitu (habitus $\mathrm{x}$ modal) + ranah = praktik. Dalam kaitannya dengan hasil penelitian di atas, maka kegiatan perjalanan spiritual yang di dalamnya sarat akan kegiatan wisata telah dimaknai sebagai sebagai praktik yang biasa dilakukan, sehingga dirasakan sebagai tindakan yang bersifat praktis untuk dilakukan. Tentunya untuk mewujudkan hal tersebut para pelakunya harus memiliki modal ekonomi berupa uang. Modal sosial berupa hubungan dengan pengusaha biro perjalanan wisata untuk menangani perjalanannya, modal budaya berupa pengetahuan dan informasi awal tentang tempat yang akan dikunjungi. Bila ketiga modal tersebut digunakan, maka mereka akan memperoleh modal simbolik berupa sebutan, julukan ataupun stigma positif bahwa mereka adalah seorang yang religius.

Demikian juga pertukaran di antara modal yang satu dengan yang lain dapat saja berlangsung dalam perjalanan wisata spiritual tersebut, dengan menggunakan modal ekonomi maka para pelaku bisa mendapatkan modal budaya berupa pengetahuan akan tempat suci, dan objek wisata pada satu sisi. Sedang pada sisi yang lain mereka juga memperoleh modal sosial berupa jaringan hubungan dengan pengusaha biro perjalanan, pemandu wisata, ataupun hubungan relasional lainnya yang dapat terjalin selama perjalanan. Sementara ranah yang dimaksudkan dalam hal ini adalah suatu tatanan sosial yang telah terbentuk dari revitalisasi perjalanan spiritual tersebut, yang mana terbentuknya tatanan sosial tersebut tanpa mereka sadari, dan bukan hal yang mereka sengaja kehendaki. 


\section{Perjalanan Spiritual sebagai Paket Wisata}

Untuk keberimbangan dalam pembahasan dalam penelitian ini, maka setelah membahas pola perilaku perjalanan spiritual konvensional yang dilakukan masyarakat yang bergeser menjadi penggabungan konsep perjalanan spiritual dan perjalanan wisata, maka akan dibahas juga dari sudut pengusaha. Seperti diketahui para pengusaha biro perjalanan berperan sangat penting dalam mewujudkan perjalanan spiritual menjadi satu produk paket wisata. PT. Bali Daksina Wisata yang untuk selanjutnya disingkat BDW adalah salah satu biro perjalanan yang dikenal luas sebagai penyelenggara kegiatan Tirta Yatra oleh masyarakat, dan instansi pemerintah di Bali.

Seiring dengan meningkatnya kesadaran masyarakat terhadap pemahaman agama, kencangnya arus perubahan yang dibawa oleh globalisasi sehingga menyebabkan masyarakat tidak memiliki keterbatasan dalam ruang geraknya. Keinginan masyarakat untuk mengetahui lingkungan luar di luar daerahnya sendiri juga semakin kuat. Jarak tempuh antar provinsi bukanlah menjadi kendala dan penghalang seseorang atau sekelompok orang untuk melakukan perjalanan. Piliang (2004:50) menyebutnya sebagai pemampatan ruang dan waktu, merupakan cara menjadikan jarak di dalam ruang semakin kecil, dengan memperkecil waktu yang diperlukan dalam pergerakan di dalamnya. Lewat penemuan teknologi muthakhir, khususnya teknologi transportasi, telekomunikasi, dan informasi, jarak-ruang semakin kecil.

Sebagai perusahaan yang bergerak di bidang kepariwisataan, BDW menangkap peluang pengembangan untuk menggabungkan kegiatan perjalanan spiritual mengunjungi tempat-tempat suci di luar Bali, sekaligus menyisipkan kunjungan ke objek-objek wisata. Maka pada tahun 2010 BDW meluncurkan konsep "Paket Tirta Yatra". Banyak paket tirta yatra lain yang ditawarkan oleh pihak BDW, dan tidak terbatas tujuan ke luar Bali saja seperti yang disebutkan di atas, tetapi juga hingga ke luar negeri seperti India. Untuk Tirta Yatra ke luar wilayah Bali, sebenarnya tidak terbatas hanya meggunakan alat transportasi udara, tetapi juga menggunakan transportasi darat seperti bus dan minibus, yang disesuaikan dengan kebutuhan dan jumlah peserta. Perjalanan darat tesebut mereka istilahkan dengan Paket Tirtayatra (Overland). Dalam penawaran paket Tirtayatra tersebut pihak BDW mewujudkannya dalam brosur yang memuat setiap paket, dan proposal yang memuat seluruh paket Tirtayatra yang mereka tawarkan. Baik pada brosur dan proposal, pihak BDW mencantumkan harga yang dikenakan pada masing-masing peserta, harga paket sudah termasuk untuk keperluan apa, serta harga paket tidak termasuk apa saja (akomodasi hotel, tiket pesawat, airport tax, transportasi bus wisata full AC selama di tujuan, satu orang tour leader dari BDW, local guide, fasilitas makan pagi, siang, dan malam, serta operasional parkir, porter bandara, hotel, dan tiket masuk objek wisata), beserta minimum jumlah peserta yang bisa diberangkatkan.

Pihak biro perjalanan juga memasang iklan tentang paket Tirtayatra pada media cetak seperti pada koran harian lokal yang terbit di Bali. Selain itu secara rutin mereka juga melakukan penawaran ke instansi pemerintah dan swasta. Hal ini sebagaimana diungkapkan oleh Marketing Manajer BDW I Gede Sutawan, bahwa pada awalnya merekalah yang menawarkan paket Tirtayatra tersebut ke instansi pemerintah yang ada di Kota Denpasar dan Propinsi Bali. Tawaran tersebut langsung mendapat respon positif, rupanya peserta Tirtayatra yang sebagian besar merupakan PNS tersebut sangat senang dengan penggabungan kegiatan bersembahyang ke purapura di luar Bali, dan ditambah ataupun diselingi dengan kunjungan ke objek wisata, serta wisata shoping ke pusat-pusat perbelanjaan. Kepuasan peserta tersebut kemudian ditindaklanjuti dengan mengajak keluarganya, ataupun teman-teman dilingkungannya untuk melakukan paket Tirtayatra bersama BDW. Hingga akhirnya BDW saat ini lebih dikenal sebagai travel penyelenggara Tirtayatra, karena besarnya permintaan akan paket Tirtayatra tersebut, terutama untuk Paket Tirtayatra Gunung Salak perwakilan BDW di Jakarta yang ditugasi mengurus segala keperluan peserta sering merasa kewalahan, bahkan guide freelance yang mereka miliki tidak pernah sempat menangani perjalanan yang diadakan oleh travel lain. Sebagaimana diakui oleh Negarawan yang lebih dikenal dengan nama Yoyok, seorang guide freelance yang biasa menangani tamu-tamu dari BDW jika mengikuti Tirtayatra ke Gunung Salak. "Saya sebenarnya guide freelance untuk BDW perwakilan Jakarta, tapi karena tamu-tamu dari BDW Bali terutama yang ikut Tirtayatra sangat banyak, dan terus bersambung ngak pernah putus, jadinya saya ngak sempat ambil kerjaan 
lain," ungkap Yoyok menceritakan betapa tingginya minat orang Bali untuk mengikuti Tirtayatra.

Sangat menarik untuk dicermati bahwa paket perjalanan mengunjungi tempat-tempat suci berhasil dipadukan dengan mengunjungi tempat wisata, bahkan juga mengakomodir kesenangan masyarakat Bali untuk berbelanja. Semua yang ditawarkan tak ubahnya sebagai "paket komplit", sambil bersembahyang sambil berwisata. Inilah sebuah wujud revitalisasi dari wisata spiritual, ia tak ubahnya seperti paket makanan siap saji yang kini marak menawarkan paket komplit. Seperti satu paket McDonald, dan KFC, pada satu paket sudah terisi nasi, ayam goreng, dan minuman beserta puding sebagai hidangan penutup. Tentu sisi kepraktisan dari paket tesebut sangatlah menonjol. Inilah sebuah era dimana semua hal dituntut untuk terjadi dengan cepat, instan, proses yang biasanya mengiringinya seakan tidak penting. Ritzer (dalam Piliang, 2004:289) melihat "McDonald's sebagai sebuah simbol utama dari homogenitas dunia ini, yang menciptakan kecenderungan sosial, politik, ekonomi, da budaya global, yang disebut McDonaldisasi". Terkait dengan bidang keagamaan dan kegiatan spiritual, McDonaldisasi telah mempengaruhi timbulnya paket Tirtayatra yang ditawarkan oleh travel. Kegiatan tersebut bukanlah murni kegiatan Tirtayatra seperti yang dikenal dan telah dilakukan masyarakat Hindu di Bali sejak dahulu. Kini tujuan utama dari perjalanan itu tetaplah melakukan persembahyangan, yang membutuhkan waktu tidak lebih dari setengah hari selanjutnya diisi penuh dengan kegiatan berwisata dan shoping, bahkan bisa memakan waktu 2 (tiga) hari. Terkait dengan konsep dan teori dalam penelitian ini, maka dapatlah dinyatakan bahwa kapitalisme telah merambah bidang spiritual melalui penjualan paket Tirtayatra tersebut oleh pihak travel. Hal tersebut dinyatakan sebagai ekspansi kapitalisme di bidang pariwisata, dikarenakan penjualan paket tersebut tentunya diarahkan untuk meraih keuntungan sebesar-besarnya, dengan melibatkan pengusaha yang bergerak di bidang transportasi, rumah makan atau restoran, penyedia penginapan ataupun hotel, penjual sovenir, dan barangbarang kerajinan, hingga menggandeng orang yang bisa membuat banten guna memberi layanan penyediaan banten kepada peserta Tirtayatra. Belum lagi perlunya kerjasama dengan pemangku (tokoh agama) yang biasanya bertugas di areal sebuah pura, dan juga masyarakat di sekitar pura. Kesemua komponen tersebut merupakan jejaring kapitalisme yang benar-benar bergerak aktif dalam bisnis penjualan paket Tirtayatra. Sedangkan teori yang dapat menjelaskan adalah Teori Wacana Pengetahuan Kekuasaan bahwa pengetahuan memungkinkan adanya kekuasaan demikian pula sebaliknya. Terhubung dengan penelitian ini karena pengetahuan yang dimiliki oleh BDW sebagai perusahaan biro perjalanan wisata tentang objekobjek wisata, tempat suci (pura), pusat perbelanjaan, pemilik dan pengelola hotel serta restoran, maskapai penerbangan, dan pihak-pihak terkait lainya, maka BDW menjadi pihak yang berkuasa dalam penentuan paket Tirtayatra tersebut.

\section{SIMPULAN}

Berdasarkan uraian dalam hasil dan pembahasan maka dapat ditarik kesimpulan sebagai berikut. Wujud revitalisasi wisata spiritual adalah adanya perubahan pola dan cara yang dilakukan masyarakat dalam melakukan perjalanan spiritual. Dari yang awalnya hanya untuk melakukan satu tujuan yakni perjalanan spiritual semata yang peneliti istilahkan dengan perjalanan spiritual konvensional. Seiring perkembangan waktu, globalisasi di segala bidang kehidupan menyebabkan transformasi perilaku dalam melakukan perjalanan spiritual, dimana kegiatan tersebut digabungkan dengan kegiatan wisata mengunjungi objek-objek wisata dan pusat perbelanjaan. Dengan demikian kegiatan perjalanan spiritual telah mengalami revitalisasi dari bentuknya semula akibat merambahnya kapitalisme di bidang keagamaan melalui kegiatan kepariwisataan. Adapun wujud nyata dari ekspansi kapitalisme adalah keterlibatan pengusaha biro perjalanan wisata beserta komponen-komponennya dalam menjual paket perjalanan wisata spiritual.

Hal-hal yang dapat direkomendasikan dan perlu mendapatkan perhatian baik dari masyarakat, maupun BPW adalah, meskipun dengan alasan kepraktisan namun hendaknya kegiatan wisata spiritual tetap memberikan porsi waktu yang lebih banyak terhadap kegiatan keagamaan sebab selama ini paket perjalanan wisata spiritual yang ditawarkan oleh BPW lebih menfokuskan diri pada kegiatan berwisata. Masyarakat yang melakukan perjalanan wisata spiritual hendaknya memainkan posisi strategis dalam menentukan rute dan tujuan perjalanan 
sehingga dapat memenuhi aspek perjalanan spiritual daripada mengikuti seluruh arahan dari BPW sebagai penyelenggara yang tentu saja lebih mementingkan sisi ekonomi.

\section{DAFTAR PUSTAKA}

Abdullah, Irwan. 2006. Kontruksi dan Reproduksi Kebudayaan. Yogyakarta: Pustaka Pelajar.

Featherstone, Mike. 2001. Postmodernisme dan Budaya Konsumen (penerjemah: Misbah Zulfa Elizabeth). Yogyakarta : Penerbit Pustaka Pelajar.

Habermas, Jurgen. 2006. Teori Tindakan Komunikatif. Buku I dan Rasionalisasi Masyarakat. Yogyakarta: Kreasi Wacana.

Harker, Richard., Mahar, Cheen \& Wilkes, Chris. .1990. (Habitus $\times$ Modal) + Ranah = Praktik; Pengantar Paling Komprehensif Kepada Pemikiran Piere Bourdieu. Yogyakarta: Jala Sutra.

Haryatmoko. 2002. "Kekuasaan Melahirkan AntiKuasa Menelanjangi Mekanisme dan Teknik Kekuasaan Bersama Foucault" dalam Basis Menembus Fakta Konfrontasi Foucault \&
Mark Nomor 01-02 Tahun ke 51 Januari Pebruari. Yogyakarta: Kanisius.

Muljadi, A.J. 2009. Kepariwisataan dan Perjalanan. Jakarta : PT. Raja Grafindo Persada.

Piliang, Yasraf Amir. 2004. Dunia Yang Dilipat Tamasya Melampaui Batas-batas Kebudayaan. Bandung : Jalasutra.

Riskia, Tri Santy Maylinda. 2009. Potensi Objek Wisata Budaya dan Spiritual di Kabupaten Wonogiri. http// www.dglib.uns.ac.id/ diakses tanggal 10 Mei 2013.

Sunary. 2013. Budaya Spiritual Petilasan-Petilasan di Gunung Selok dalam Konteks Pemahaman oleh Masyarakatnya. Universitas Negeri Semarang http://garuda.kemdiknas.go.id diakses tanggal 10 Mei 2013.

Sztompka, Piotr. 2004. Sosiologi Perubahan Sosial (penerjemah: Alimanda). Jakarta : Prenada Media Group.

Anonim, Undang-undang No. 10 Tahun 2009 tentang Kepariwisataan. 